\title{
質量分析イメージングの創薬研究への展開
}

\author{
早坂孝宏
}

\section{Application of Imaging Mass Spectrometry for Drug Discovery}

\author{
Takahiro Hayasaka \\ Hokkaido University; Kita 12, Nishi 5, Kita-ku, Sapporo 060-0812, Japan.
}

(Received August 5, 2015)

\begin{abstract}
Imaging mass spectrometry (IMS) can reveal the distribution of biomolecules on tissue sections. In this process, the biomolecules are directly ionized within tissue sections using matrix-assisted laser desorption/ionization, and then their distribution is visualized by pseudo-color based on the relative signal intensity. The biomolecules, such as fatty acids, phospholipids, glycolipids, peptides, proteins, and neurotransmitters, have been analyzed at a spatial resolution of $5 \mu \mathrm{m}$. A special instrument for IMS analysis was developed by Shimadzu. The IMS analysis does not require the labeling of biomolecules and is capable of analyzing all the ionized biomolecules. Interest in this method has expanded to many research fields, including biology, agriculture, medicine, and pharmacology. The technique is especially relevant to the drug discovery process. As practiced currently, drug discovery is expensive and time consuming, requiring the preparation of probes for each drug and its metabolites, followed by systematic probe tracking in animal models. The IMS technique is expected to overcome these drawbacks by revealing the distribution of drugs and their metabolites using only a single analysis. In this symposium, I introduced the methodology and applications of IMS and discussed the feasibility of its application to drug discovery in the near future.
\end{abstract}

Key words__ imaging mass spectrometry; drug discovery; lipid; fatty acid

\section{1. はじめに}

質量分析計の感度向上に伴い多くの物質を一度に 検出することが可能になった. 1990 年代に入ると 初めて質量分析イメージングが試みられるように なつた．質量分析イメージングという用語はいまだ その呼称が統一されておらず，世界的にもイメージ ング質量分析や質量分析法（mass spectrometry） の略語である MS を用いて MS イメージングなど とも呼ばれている。 日本においてもそれらとともに 質量顕微鏡という呼称が作られている.11 この質量 顕微鏡という呼称は，われわれ日本人の感覚から言 うと最も適切に表現した言葉なのかもしれない.な ぜなら質量分析イメージングは，質量分析法と顕微 鏡法が合わさつた手法だからである。これらの $2 つ$ の手法のよい点を取り入れた手法が質量分析イメー ジングと言える. 質量分析法では, 試料から精製し

北海道大学（=060-0812 札幌市北区北 12 条西 5丁目）

e-mail: thaya@hs.hokudai.ac.jp

本総説は, 日本薬学会第 135 年会シンポジウムS50 で 発表した内容を中心に記述したものである.
た分子を多段階質量分析することにより分子構造を 解析することが可能であり，その威力を発揮してき た. 一方で試料中における分子の位置情報が失われ るという久点があつた。 また顕微鏡法では, 既知分 子の構造情報を基にした抗体などを標識することに より，その分布を高解像度で観察することが可能で ある. その反面, 構造情報が明らかになっている分 子に観察が限定される課題が残されたままである.

質量分析イメージングでは，試料中における分子の 位置情報を明らかにし, その分子の構造解析を行う ことが可能である. 特に一度の解析によりイオン化 し検出されたイオン群のすべてが解析対象となると いう利点がある.

\section{2. 質量分析イメージングの流れ}

質量分析イメージングの流れについて説明す る. ${ }^{1)}$ 解析対象となるのは細胞や組織切片である. これらをスライドガラス上に貼り付けることが最初 の作業となる。一般的なスライドガラスや導電性素 材をコーティングした特殊なスライドガラスなどが 利用され, 解析に用いる装置によつて使い分けるこ 
とになる。質量分析イメージングに用いられるイオ ン化法の主流はマトリックス支援レーザー脱離イオ ン化法 (matrix-assisted laser desorption/ionization; MALDI）である。MALDI ではマトリックスと呼 ばれる有機化合物と分子の共結晶を形成し，そこに レーザーを照射することによりイオン化させる手法 である。質量分析イメージングでは試料に対して均 一にマトリックスを塗布する必要がある。マトリッ クスと分子の比はイオン化に大きく影響を与えるた めである。その塗布方法として，これまではマト リックス溶液を手動若しくは市販の装置を用いて自 動的に塗布する方法が採用されてきた。近年になり マトリックス粉末を真空中で昇華させることによ り，上面に設置した試料に対して均一に塗布する蒸 着法も頻繁に利用されるようになってきた。均一に マトリックスを塗布された試料は質量分析計に導入 され，測定する試料領域が決定される。この際に測 定点の間隔を設定することで，合計の測定点が決定 される．測定点が多いほどデー夕容量は膨大にな る。また測定する質量範囲の広さもスペクトルを形 成するデータポイント数に関係するため, 広い質量 範囲を設定すれば，それだけデータ容量を大きくす る要因となる。このデー夕容量が $1 \mathrm{~GB}$ を超えるこ ともあり, 経験のない研究者には驚かれることもし ばしばである。また合計の測定点が多くなれば，測 定に要する時間も長くなり，10 時間を超えること もある。このようにして取得されたデー夕は，測定 点毎のマススペクトルという質量情報で構成され る. 専用のソフトウェアを用いてマススペクトル中 の任意のシグナルを選択することによって，そのシ グナルの各測定点におけるシグナル強度が比較さ れ，その相対比に応じた疑似色によって試料上にお けるシグナルの分布が示される。それらのシグナル の構造情報を明らかにすることも非常に重要な作業 である. 質量分析イメージングで取得されるシグナ ルは，通常の質量分析法と同様に複数の分子が混在 する試料を測定した場合に基本的には多く存在する 分子が強いシグナルとして検出される。これを組織 上で考えた場合には，組織を構成する主要な分子が 検出されることになり，一般的な試料であれば既知 の分子が検出されることになる，よってそれらの分 子に関する構造情報はデータベースや論文で報告さ れているものばかりである．組織上で検出された任
意のシグナルを選択し，そのイオンだけを断片化さ せ，その断片化パターンから分子構造を明らかにす ることが可能である。ここまでの話からすると，顕 微鏡法が得意としている既知の分子を標識すること と変わらないと思われるかもしれない。しかし質量 分析イメージングが注目を集めるようになつた $1 つ$ の要因として，脂質を解析対象とすることが挙げら れる，脂質には生体膜を構成する主要成分であるリ ン脂質に代表されるように複数の脂肪酸で構成さ れ，その組成によって生体での働きが変わるといっ たことが知られてきている，そのような脂肪酸組成 の違いまで解析可能な手法は今のところ質量分析イ メージングのほかに存在しないのである．また解析 対象には脂質だけでなく，タンパク質，アミノ酸， 糖，脂肪酸，薬物といつた様々な分子がある点も大 きな特徵と言える.

\section{3. 質量分析イメージングが可能な装置}

イオン化法に MALDIを採用した最近の装置 は，その多くが質量分析イメージングを実施するこ とが可能となっている. Shimadzu，JEOL，Thermo Scientific, Bruker Daltonics, Waters, AB SCIEX な ど，それぞれ独自の装置を開発し，市販している. 質量分析計の構成は装置によって様々である. MALDI によってイオン化されると分子イオンは検 出器へ到達するまでに, 様々な手法によって分離す ることが可能である。一般的な分離方法としては飛 行時間型質量分析計 (time-of-flight MS; TOF-MS) が存在する．分子イオンは電圧によって加速され真 空中を飛行する際，その重さによって速度が異なる ため, 検出器への到達時間が変わる. 小さい分子イ オンは早く検出器へ到達し, 大きい分子イオンは ゆっくりと検出器へ到達するといつた具合である. これらの時間を質量電荷比 $(\mathrm{m} / \mathrm{z})$ へ変換すること によって分子イオンの重さとして表すことができ る.この TOF の前に四重極やイオントラップを設 置する場合もある，四重極は分子イオンが通過する 際に直流電圧と交流電圧を印加することによって電 場を発生させ，目的の分子イオンだけを通過させる ことができる.イオントラップも同様にして目的の 分子イオンだけを通過させることもできるが, さら にイオントラップ内で分子イオンの開裂を引き起こ させ, 断片化したイオンを検出器で測定することも 可能である.オールマイティな装置は今のところ存 
在しておらず，研究者の目的に応じた装置をチョイ スすることになる．価格は数千万円から 1 億円を超 えるものまで存在するため簡単な買い物ではない. しかしながら購入することを目的とした場合には， 各社のラボでデモンストレーションをしてもらえる ことが多いので問い合わせてみることも 1 つの手と 考えられる。

\section{4. iMScope $の$ 開発}

筆者が質量分析イメージングに取り組み始めたの は，2007 年からである。当初はマトリックス塗布 を自動で行えるような装置もなく，プラモデル製作 に用いられるカラーリング用の手動スプレイヤーを 利用していた。 それと同時に島津製作所，がん研究 会, 慶應義塾大学らとの共同研究により質量分析イ メージング用の質量分析計の開発にも携わってい た。その装置は無事に完成し，2014 年春に iMScope という商品として販売が開始された。iMScope のコンセプトは顕微鏡で観察した箇所を質量 分析し，そこに存在する分子群の局在を可視化する というものであった．MALDI チャンバーを大気圧 に設定することにより光学顕微鏡を配置し，40 倍

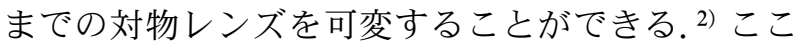
で観察した試料から測定領域を始めとした測定条件 を設定し，隣のレーザー照射部へ試料を運搬する. レーザー照射が行われると, 試料表面で分子がイオ ン化され試料導入部，イオンガイドを通過し，四重 極イオントラップによって分子イオンが捕獲され る. 直流電圧と交流電圧の調節により目的の分子イ オンだけが残された後，TOF で分離された各分子 イオンのシグナル強度が検出器によって測定される という流れである。この装置ではレーザー照射部を $5 \mu \mathrm{m}$ まで収束させたことによる高解像度，四重極 イオントラップによる飛行開始点のリセットによる 高分解能測定が可能になった。 よって微小な試料領 域でも細かなピクセルによって高解像度の分子分布 を描くことができ，わずかな $m / z$ 值の差を持つ分 子を分けることによって，より固有の分子分布を描 くことに近づくことを可能にしている.

\section{5. 前処理法の手法の開発}

5-1. 脱塩処理 質量分析法ではイオンの測定 を行うものであり, その荷電は分子構造に依存して プラスとマイナスに分かれる. MALDI の場合，そ のイオン形式はマイナスの場合は単純にプロトンが
引き抜かれただけであるが，プラスの場合は試料中 に含まれる塩が影響することでプロトン，ナトリウ ム，カリウムなどが付加した形式をとる．よってプ ラスチャージを測定するポジティブイオンモードで は，1つの分子につき少なくとも 3 種のイオン形式 が存在することになり，そのスペクトルの解読は難 解である。 そのため試料中の塩を取り除く脱塩操作 が前処理に取り入れられてきた。筆者が行った脱塩 は酢酸アンモニウムや超純水を用いたものであり, これらの溶液に切片を貼り付けたスライドガラスご と 30 秒から 1 分ほど浸すことによって脱塩を行っ た。 サンプルとしてラット脳切片を脱塩した結果を 示す (Fig. 1). 脱塩を行っていない切片からは多 くの種類のシグナルを検出したものの, シグナル強 度自体は低い結果となった。一方で酢酸アンモニウ ムや超純水で脱塩処理を行った切片からは，4 倍ほ どのシグナル強度の増加を示しただけでなく,$m / z$ 800 前後のシグナルの数が減少する結果となった. 脱塩を行っていない切片から検出されたシグナルの うち, $m / z 760.5, m / z 782.5, m / z 798.5$ は同一分子 のプロトン付加, ナトリウム付加, カリウム付加で あることが分かっている. 脱塩処理した切片では, これらのシグナルがプロトン付加体である $m / z$ 760.5 に統一されていることが分かる.ナトリウム 及びカリウム付加体として検出されていたシグナル がプロトン付加体へ移行したことによりシグナル強 度が増加したことが分かる. 以上のように酢酸アン モニウムや超純水を用いて脱塩を行うことにより， イオン形式をプロトン付加体に統一し，マススペク トルを単純化することが可能である。 またシグナル 強度が増加することから後に行う可能性がある多段 階質量分析にも耐え得るシグナル強度を稼ぐことが 可能である. また脱塩を行わない場合に起こり得る 問題がもう 1 つ存在する. 別々の分子のプロトン付 加体やナトリウム付加体が同一の $m / z$ 值を示すこ とがある場合である (Fig. 2)，このとき，その $m / z$ 值を基準として分子分布を描くと，それぞれのシグ ナルが紛れ込んだイメージを表示することになり, 1 つの分子分布を表すことができない.このような 場合も想定した場合に脱塩処理が有効な手段とな る. 塩を除く脱塩に対して, 塩を加える処理も存在 する。一般的な MALDI でも用いられる手法であ るが, 数 $10 \mathrm{mM}$ 程度の塩をあらかじめマトリック 

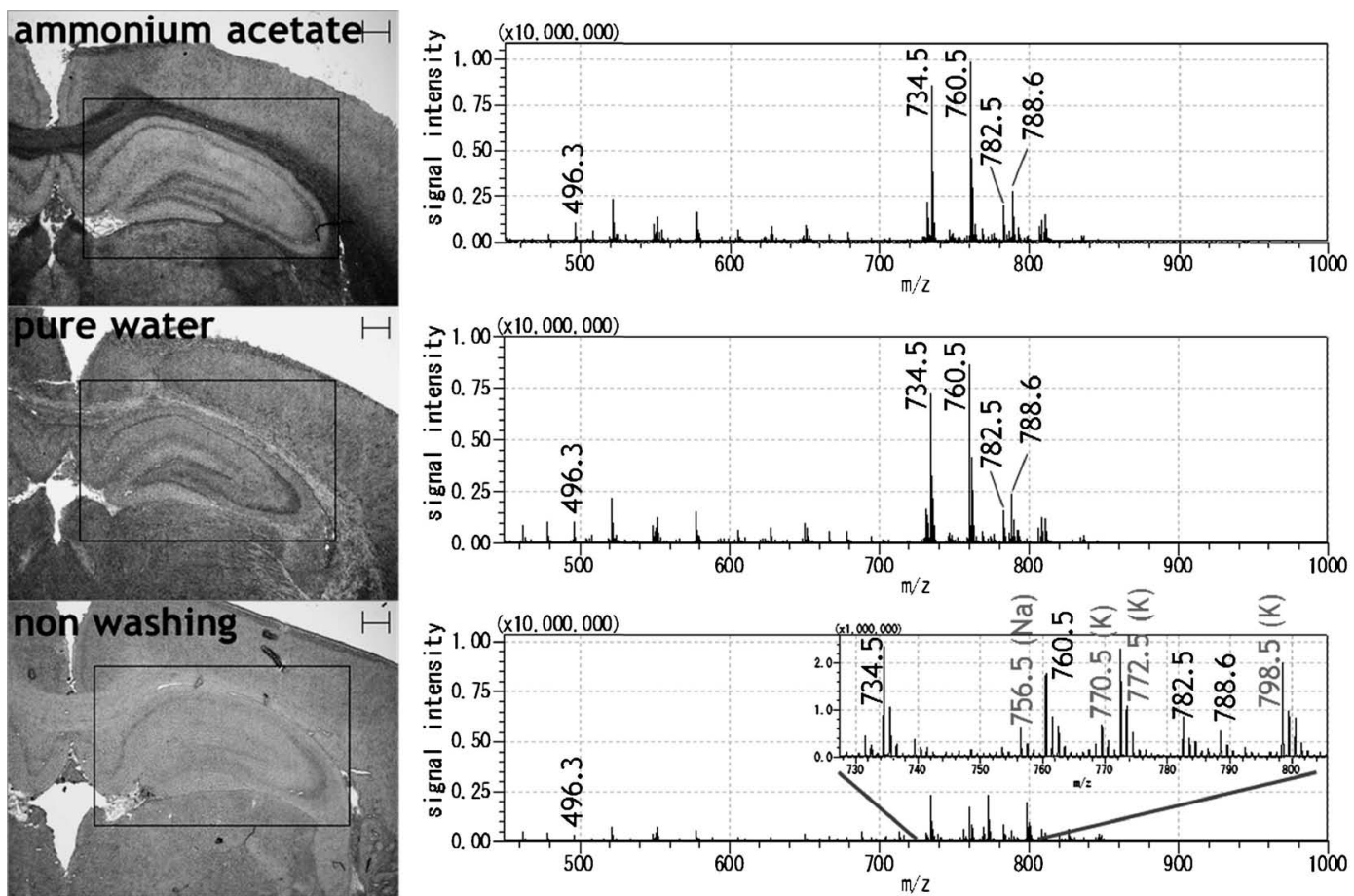

Fig. 1. Mass Spectra from a Rat Brain Desalted by Ammonium Acetate and Pure Water All ions were integrated to the ion form $\mathrm{M}+\mathrm{H}$ by treatment of a tissue section with ammonium acetate and pure water.

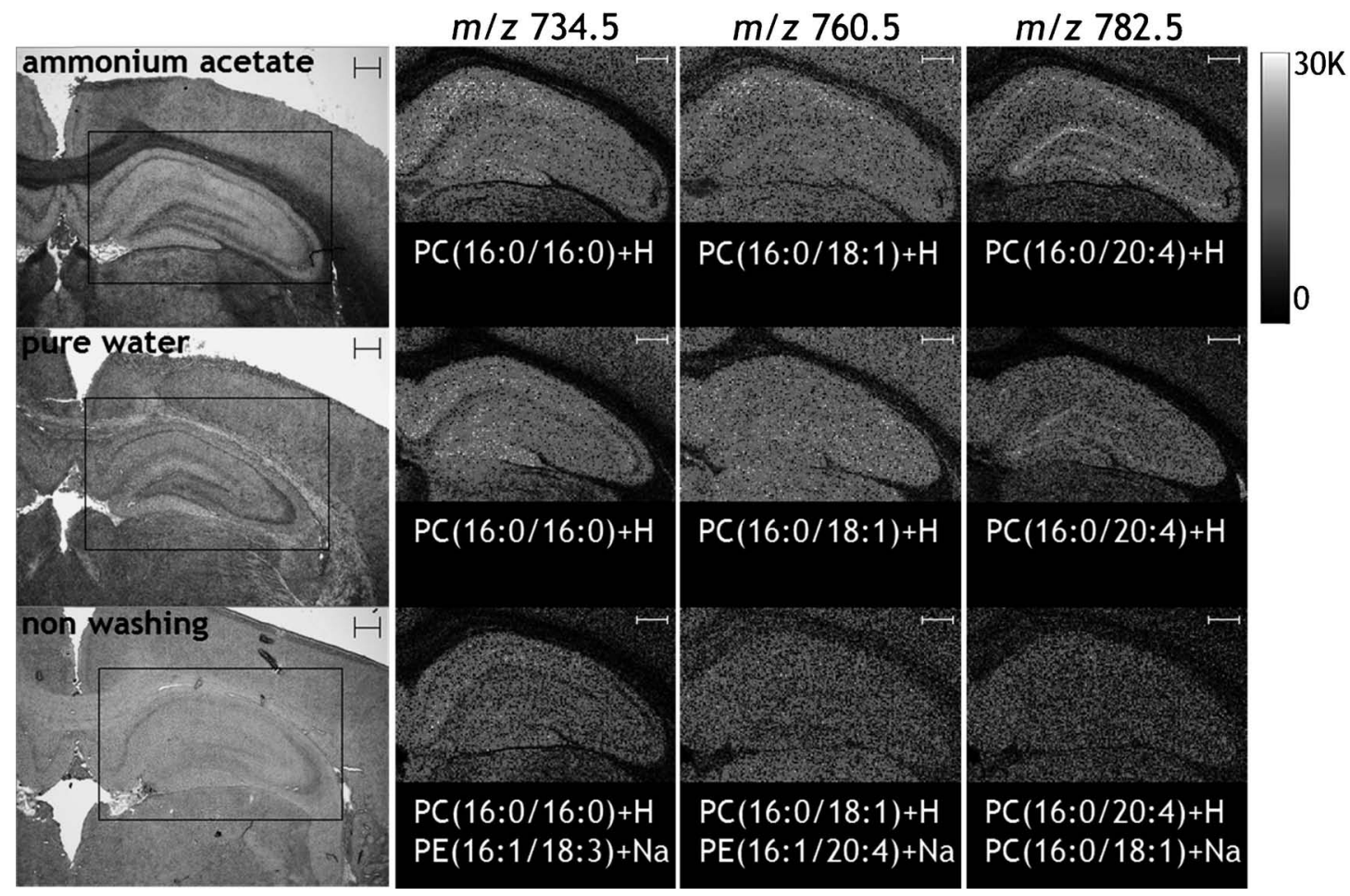

Fig. 2. Ion Images of Phospholipids in a Rat Brain Desalted by Ammonium Acetate and Pure Water The contamination of ion signals was removed from the ion images by desalting. 
スに混合し，試料に対して噴霧することによりイオ ンの付加体をその塩に偏らせる方法である. 塩とし ては生体内に存在するナトリウムやカリウムであっ たり，生体内には存在しないリチウムが用いられ る，検出される結果に応じて，これらの手法を組み 合わせることにより，解析し易いデー夕を取得する ことが可能となる.

5-2. 金属ナノ粒子の応用 マトリックスとし て一般的に用いられる有機化合物以外にもマトリッ クスとしての効果を有する物質が存在する。 その中 で金属ナノ粒子について紹介させて頂く，金属ナノ 粒子は核に金属を有し，安定性を生み出すために核 周囲を炭素差でカップリングした粒子である．われ われが用いてきた金属ナノ粒子は，銀と金を核にし たものである.これらをへキサンに溶解することに よって拡散性を有し，スプレイヤーでの塗布が可能 になった。これらを組織切片へ塗布すると，銀ナノ 粒子の場合には $m / z 400$ 以下の質量領域で多くの シグナルを検出し，それらが脂肪酸であることが明

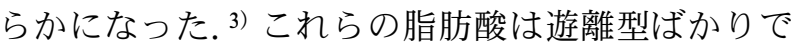
はない.リン脂質を金属プレート上に滴下した上で 銀ナノ粒子をコーティングしレーザー照射したとこ ろ, 脂肪酸が検出された。つまりリン脂質を構成す る脂肪酸がレーザー照射によって与えられたエネル ギーによって断片化し検出されたことになる，当時 の報告では脂肪酸のイメージングは初めてであっ た。その後，9-aminoacridine というマトリックス を用いることによって，上記の現象が起こることが 分かっており，特殊な金属ナノ粒子の合成を要する ことなく脂肪酸のイメージングが行えるようになつ てきている．また金ナノ粒子がマウス脳切片を試料 とした場合のマススペクトルが通常のマトリックス と比較された。 その結果, 多種のガングリオシドの イオン化効率を促進することが示され，これによつ て取得されたイメージングデータから鮮明な分布が

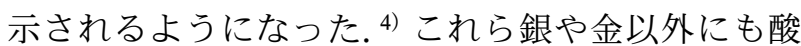
化チタン5゙は，様々な金ナノ粒子が試されてき た。それらによって取得されたマススペクトルには 分子同定が終わっていないシグナルも含まれてお り，まだまだ解析の余地があるところである.

5-3. マトリックス塗布方法の検討 質量分析 イメージングの流れについて説明をした際にマト リックス塗布方法として蒸着法が行われるように
なってきたことに触れた．蒸着法は真空中のチャン バー内に置いたマトリックス粉末を加熱することに よって昇華させ，上部に設置した組織切片に対して マトリックスを塗布する方法である。この塗布によ り, 組織切片には均一なマトリックス層がコーティ ングされる，マトリックス粉末と組織切片の設置間 隔を調節することにより，塗布範囲を調節すること も可能である.この手法ではチャンバー内の圧力と マトリックスにかける加熱温度と時間を一定にする ことにより，常に同じ厚さのマトリックス層を形成 することが可能になる．最近ではメーカーから自動 蒸着装置も市販されている。また電子顕微鏡観察を 行ったことのある方であればご存知かもしれない が，薄膜形成用の蒸着装置でも応用が可能である. この蒸着法により形成されるマトリックス層は，マ トリックスが大きな塊を作ることなく，微小な結晶 が敷き詰められたような膜を形成する，近年の装置 開発において MALDI のレーザー径も $5 \mu \mathrm{m}$ 程度ま で収束されているように，スプレイヤーを用いた手 動塗布では熟練者でも対応する微小なマトリックス 結晶を作製することが難しい。 よってマトリックス 結晶の均一性や取得データの再現性を考慮すると, 今後は蒸着法を主流として解析が進められるように なる可能性は十分にある。実際にスプレイヤーを用 いた手動塗布と蒸着法により同一マトリックスを塗 布した例をご紹介する。 ${ }^{6}$ 用いた試料はラット脳か ら作製した冠状面の組織切片である。 上部に位置す る大脳の端を中心に脳内部と外部，つまりは組織が 存在しない領域を測定した。塗布したマトリックス は 2,5-dihydroxyacetophenone であり，スプレイ

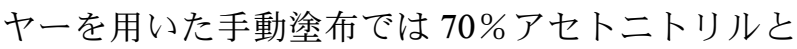
70\%エタノールで溶解した上で塗布を行った。これ らの切片から $m / z 1544$ 及び $m / z 1572$ の生体分子 シグナルを対象として, 蒸着法との比較解析を行つ た。この際のレーザー照射間隔は $10 \mu \mathrm{m}$ とした. その結果, 手動塗布した試料から得られたシグナル の分布は組織内で集中しているものの，組織外にも 多くのシグナルが検出されるといつた結果になつ た．その傾向は 70\%アセトニトリルを用いた方で 顕著であった。アセトニトリルとエタノールの揮発 性から考えると，エタノールは塗布後にすぐに揮発 するもののアセトニトリルは揮発に時間がかかるた め，組織中の分子を引き込んで，さらには組織外へ 
漏れ出てしまうことが考えられた。一方で蒸着法に よりマトリックスを塗布した試料では，組織外でほ とんどシグナルを検出しなかった．以上のことか ら，マトリックスの塗布法として長く利用されてき た手動塗布法は十分にシグナルを検出が可能である ものの, $10 \mu \mathrm{m}$ もの高解像度イメージングを行うに 当たつては, 組織中からの分子移動の可能性を考慮 しなくてはならない。70\%アセトニトリルと 70\% エタノールでの結果が異なつたように，このような 分子移動を抑制するには溶媒の選択も非常に重要に なる. また最も正確に分子分布を可視化したのは蒸 着法であることから, 蒸着法が高解像度イメージン グに適していることは確かである。今後も装置開発 が進み MALDI のレーザー径がさらに収束されて いくことを考えると, 蒸着法が塗布法の中で主流に なる可能性は大いに考えられる.

\section{6. 質量分析イメージングの応用}

6-1. 脂質 質量分析イメージングが最も威力 を発揮してきたのは，脂質を対象とした解析におい てである. 2008 年前後は装置に搭載されるレー ザーの径が $100 \mu \mathrm{m}$ ほどであり, 高解像度と呼べる ようなイメージング解析を行うことができなかっ た．その頃はマウス脳全体等，比較的大きな組織構 造を対象として解析が進められてきた。 その中でマ ウス眼球中の網膜を対象とした解析は当時ではかな り微小の試料として扱われた. ${ }^{7)}$ 網膜は 9 層もの層 構造を有し, 生体にとっても非常に重要な器官を司 る一部であり，加齢黄斑変性など網膜における疾患 は大きな問題であり, 最悪は失明の恐れさえある. マウス網膜の層構造は約 $200 \mu \mathrm{m}$ ほどの幅があり, これを $50 \mu \mathrm{m}$ の解像度でイメージングを行った. ポジティブイオンモードで解析した結果, 多くのシ グナルはホスファチジルコリンであった。 それらの シグナル 1 つ 1 つについて分布を調べたところ，そ の脂肪酸組成の違いにより異なる層に分布すること が明らかになった．ただし，この脂肪酸組成の同定 は簡単ではない事実がある。ポジティブイオンモー ドで脂質の多段階質量分析を行う際に，各リン脂質 に特異的な断片化のパターンが観察されるのは事実 である。しかし脂肪酸組成を示す断片化シグナルが 検出され難いため, 研究者の粘り強いデー夕取得が 必要となってくる. 近年には海外の研究グループも 網膜を対象とした研究を盛んに進めるようになり,
さらに高解像度のイメージング解析を導入し，また ネガティブイオンモードを交えたリン脂質の網羅的 な局在解析を進めるようになっている。 ネガティブ イオンモードでの多段階質量分析は前述のポジティ ブイオンモードとは異なり，断片化した脂肪酸がそ のままシグナルとして検出されるため, その脂肪酸 組成を簡単に明らかにすることができる。近い将 来，リン脂質の局在変動が及ぼす病理疾患への影響 が本格的に議論されるようになると考えられる。

中性脂質のトリグリセリドはメタボリックシンド ロームに代表される病態への関与が大きくとり上げ られるようになり，近年では非常に注目されている 脂質である。このトリグリセリドはマウス胎児の全 身切片を解析した際に検出され，その脂肪酸組成が 明らかにされた。 ${ }^{8)}$ ホスファチジルコリンの解析で は脂肪酸組成の同定が非常に困難であったが，トリ グリセリドについては脂肪酸が外れた残りの構造が イオン化し易いことから，比較的簡単に同定するこ とが可能であった。 これらのシグナルでは 1 位と 3 位の脂肪酸が優先的に断片化し，2 位の脂肪酸が断 片化し難いという特徵が既に明らかにされている. これらのトリグリセリドは肝臓と褐色脂肪組織内に 多く存在するという分布イメージが得られ，その貯 蓄と合成への関与が示唆された。

\section{6-2. タンパク質ＭALDIによってタンパク} 質を検出することも可能である。しかしながら検出 感度は脂質等と比較すると格段に落ち，また分子同 定は非常に困難である。そこで組織切片上でトリプ シン消化を行う手法が考えられてきた．組織上で還 元アルキル化を行ったうえで均一にトリプシンを塗 布し，8 時間のインキュベーションを行う。この操 作により組織上のタンパク質はペプチドとして断片 化される，そこへマトリックスを塗布し，レーザー 照射することによって $m / z 1000$ から $\mathrm{m} / z 3000$ 程 度のイオンを検出することが可能になる。これらの シグナルについて多段階質量分析を行うことによつ てアミノ酸配列を示す断片化シグナルを検出するこ とができ，MASCOT サーチへ情報を送ることに よって同定結果が得られる。この手法を大腸がん組 織の解析へ応用した. ${ }^{9)}$ その組織中のタンパク質を 調べたところ，低，中，高と分化度の違いによって 検出されるシグナルが異なつた。すべてを同定する には至らなかったが，代表的なシグナルとしてヒス 
トン H4 やアクチンが検出された．アクチンはすべ ての分化度の大腸がん組織に均等に存在し，ヒスト ン H4 は低分化度の大腸がん組織に多く存在するこ とが明らかになった。このように大腸がんの進展に 関与する分子が特定されたことから，そのタンパク 質の合成と分解に関与する分子を他の手法を用いて 調べることによって，その進展の詳細が明らかにな る可能性がある。

6-3. 薬物 これまでの薬物動態解析にはラジ オアイソトープが主に用いられてきた。 そこには解 析対象となる薬物や代謝物を検出するためのプロー ブを必要とすることで，莫大な予算を必要とする問 題があった。質量分析イメージングの登場により, プローブを必要としない網羅的な解析が薬物動態解 析へ応用されることが期待されている．筆者らはそ の応用として H2 ブロッカーとして知られるファモ チジンの検出を試みた. ${ }^{10)}$ マウスに対してファモチ ジンを静脈から投与し，その全身切片を作製した。 マトリックス塗布後に質量分析イメージングによつ て測定したところ，ファモチジンを示す $m / z 338$ のシグナルが腎臓を中心に存在することが明らかと なった。内因性分子が同じ $m / z$ 值を示す可能性も 大いに考えられる。そこで局在の確証を得るために ファモチジンのイオンを断片化させ，そのファモチ ジン特異的な断片化シグナルの局在を検証した。 そ の結果，その分布イメージにおいても腎臓に存在す ることが示された。さらに腎臓内での高解像度イ メージングを行ったところ，ファモチジンが腎孟に 局在していることが示された．以上のように質量分 析イメージングを用いることによって，その分布の 詳細な情報を得ることができた。このような薬物動 態解析への質量分析イメージングの応用は海外にお いて特に活発に進められている，その背景には世界 規模の製薬会社が積極的に共同研究を大学に持ちか けていることが窥え，現にそれらの研究者が発表し た際の謝辞にはそれらの企業名が出されているとい う事実がある。 今後，国内においても質量分析イ メージングを採用する研究者が増えることにより， 海外のような薬物動態研究の活発化が望まれるとこ ろである。

\section{7. おわりに}

質量分析イメージングが登場してから 10 年以上 が経過した。その間に多くの研究者によって手法が
改良され，様々な分子の解析へ応用することが可能 になってきている，そして今もなおイオン化装置や 質量分析計の開発も活発に進められ，その解像度や 感度は向上する一方である．国内の研究機関におい ても装置を購入し，新たに質量分析イメージングを 用いた解析を進めている機関が増えてきた。このよ うな新しい分析技術の発展においては多分野の研究 者の参入が不可欠であり，そこから多くの新しい技 術や応用方法が生まれる可能性がある。そしてそれ らの研究成果を積極的に外部配信することにより, 質量分析イメージングの更なる発展が期待される.

謝辞 JST 研究成果展開事業（機器開発，実証 実用化，ソフトウェア開発，開発成果の活用・普及 促進）及び科学研究費補助金若手研究 (B) の研究成 果を発表したものです.

利益相反＼cjkstart開示すべき利益相反はない.

\section{REFERENCES}

1) Setou M. "Imaging Mass Spectrometry-Protocols for Mass Microscopy," Springer, Tokyo, 2010.

2) Harada T., Yuba-Kubo A., Sugiura Y., Zaima N., Hayasaka T., Goto-Inoue N., Wakui M., Suematsu M., Takeshita K., Ogawa K., Yoshida Y., Setou M., Anal. Chem., 81, 9153-9157 (2009).

3) Hayasaka T., Goto-Inoue N., Zaima N., Shrivas K., Kashiwagi Y., Yamamoto M., Nakamoto M., Setou M., J. Am. Soc. Mass Spectrom., 21, 1446-1454 (2010).

4) Goto-Inoue N., Hayasaka T., Zaima N., Kashiwagi Y., Yamamoto M., Nakamoto M., Setou M., J. Am. Soc. Mass Spectrom., 21, 1940-1943 (2010).

5) Shrivas K., Hayasaka T., Sugiura Y., Setou M., Anal. Chem., 83, 7283-7289 (2011).

6) Hayasaka T., Goto-Inoue N., Masaki N., Ikegami K., Setou M., Surf. Interface Anal., 46, 1219-1222 (2014).

7) Hayasaka T., Goto-Inoue N., Sugiura Y., Zaima N., Nakanishi H., Ohishi K., Nakanishi S., Naito T., Taguchi R., Setou M., Rapid Commun. Mass Spectrom., 22, 3415-3426 (2008). 
8) Hayasaka T., Goto-Inoue N., Zaima N., Kimura Y., Setou M., Lipids, 44, 837-848 (2009).

9) Morita Y., Ikegami K., Goto-Inoue N., Hayasaka T., Zaima N., Tanaka H., Uehara T,. Setoguchi T., Sakaguchi T., Igarashi H.,
Sugimura H., Setou M., Konno H., Cancer Sci., 101, 267-273 (2010).

10) Saito Y., Hayasaka T., Onoue K., Takizawa Y., Kajihara S., Ogawa K., Setou M., J. Mass Spectrom. Soc. Jpn., 59, 79-84 (2011). 